\title{
Strategi Penerapan Konsep Peserta Didik yang Ideal Menurut Imam Az-Zarnuji dalam Kitab Ta'Limul Muta'allim di Mahad Aly Pondok Pesantren Al- Ishlahuddiny Kediri Lombok Barat
}

\author{
Hamdani $^{1}$, Abdul Fattah ${ }^{2}$, dan Salimul Jihad ${ }^{3}$ \\ Universitas Islam Negeri Mataram, Nusa Tenggara Barat, Indonesia \\ email: ${ }^{1 h}$ amdanialfata@gmail.com
}

\begin{abstract}
The Book of Ta'limul Muta'allim is one of a series of yellow books which are widely studied and become guidelines for santri in Islamic boarding schools. Al-Ishlahuddiny Islamic Boarding School Kediri Lobar is one of the huts that studies the book Ta'limul Muta'allim, and the book in the al-Ishlahuddiny boarding school is used as a reference to form students who become moral children, this cottage is not it sounds strange because this cottage is one of the oldest cottages in Lombok. This cottage, when viewed from the output side, has printed many polite students, tawaddu ', waro', preachers, experts in yellow books and become ustaz ustazah and master teachers. At the alIshlahuddiny Islamic boarding school in the Mahad Aly section of the institution, the contents of the book Ta'limul Muta'allim have been applied as a reference to form students who become moral students. The purpose of this study is to explain the strategy of applying the ideal concept of students according to imam az-Zarnuji in the book Ta'limul Muta'allim in Mahad Aly pondok pondokren al-Ishlahuddiny kediri Lombok Barat and the results of its application in the Pondok. The type of research used in this study is qualitative research that uses a phenomenological approach. For data collection used in this study are observation, interviews, and documentation. Based on the results of this study through observation, interviews, and documentation about the strategy of applying the ideal concept of students according to imam az-Zarnuji in the book Ta'limul Muta'allim in Mahad Aly Islamic boarding school al-Ishlahuddiny Kediri Lombok Barat using several strategies namely the attitude of exemplary, habituation, devotion, and giving advice. While the results of the implementation strategy are Mahad Aly students of Al-Ishlahuddiny Islamic Boarding School to be respectful to teachers and knowledge, waro ', patience and resignation and discipline.
\end{abstract}

Keywords: Implementation strategy, ideal student concept.

\begin{tabular}{|c|c|c|}
\hline $\begin{array}{l}\text { First Receive: } \\
23 \text { April } 2019\end{array}$ & $\begin{array}{l}\text { Revised: } \\
2 \text { Mei } 2019\end{array}$ & $\begin{array}{l}\text { Accepted: } \\
5 \text { Mei } 2019\end{array}$ \\
\hline $\begin{array}{c}\text { Final Proof Recieved: } \\
\text { 10 Juni } 2019\end{array}$ & \multicolumn{2}{|l|}{$\begin{array}{l}\text { Published: } \\
\text { 21 Juni } 2019\end{array}$} \\
\hline \multicolumn{3}{|c|}{ How to cite (in APA style): } \\
\hline \multicolumn{3}{|c|}{$\begin{array}{l}\text { Hamdani, Fattah, A., \& Jihad, S. (2019). Strategi Penerapan Konsep Peserta Didik } \\
\text { yang Ideal Menurut Imam Az-Zarnuji dalam Kitab Ta'Limul Muta'allim } \\
\text { di Mahad Aly Pondok Pesantren Al-Ishlahuddiny Kediri Lombok Barat. } \\
\text { Schemata, 8 (1), 1-16. }\end{array}$} \\
\hline
\end{tabular}

\section{PENDAHULUAN}

Dalam yuridis undang-undang pendidikan disebutkan bahwa pendidikan harus menjadikan peserta didiknya yang mempunyai akhlak yang mulia, artinya praktek pendidikan tidak hanya berorientasi pada aspek kognitif saja, melainkan secara terpadu menyangkut aspek afektif dan psikomotorik, sebagaimana hal tersebut dikatakan di dalam tujuan 
Hamdani, A. Fattah, dan S. Jihad, Strategi Penerapan Konsep Peserta Didik yang Ideal...

peraturan pemerintah Republik Indonesia Nomer 55 tahun 2007 terkait tentang pendidikan Agama dan Keagamaan bab 2 pasal 2 yang berbunyi: "Pendidikan agama berfungsi membentuk manusia Indonesia yang beriman dan bertakwa kepada Tuhan Yang Maha Esa serta berakhlak mulia dan mampu menjaga kedamaian serta kerukunan hubungan umat beragama". ${ }^{1}$

Kitab Ta'limul Muta'allim merupakan satu-satunya karya populer imam az-Zarnuji yang dapat diketahui dan masih ada sampai sekarang. Dan kitab ini juga merupakan salah satu dari deretan kitab kuning yang banyak dipelajari dan menjadi pedoman santri di pondok pesantren. Pondok Pesantren al-Ishlahuddiny Kediri salah satu pondok yang mengkaji kitab Ta limul Muta'allim, dan kitab tersebut di pondok pesantren al-Ishlahuddiny digunakan sebagai rujukan untuk membentuk peserta didiknya menjadi anak yang berakhlak, pondok ini di kalangan masyarakat sudah tidak asing lagi kedengarannya karena pondok ini salah satu pondok yang tertua di Lombok. Pondok ini kalau dilihat dari sisi outputnya sudah banyak mencetak peserta didiknya yang santun, tawaddu', waro', penyaabar, ahli dalam kitab kuning dan menjadi ustaz ustazah dan tuan guru. ${ }^{2}$

Pada ponpes al-Ishlahuddiny di bagian lembaga Mahad Aly telah menerapkan isi kitab Ta'limul Muta'allim sebagai rujukan untuk membentuk peserta didiknya menjadi peserta didik yang berakhlak. ${ }^{3}$ Berangkat dari beberapa permasalahan yang dijelaskan di atas, maka perlu pengkajian dan penelitian yang lebih lanjut tentang permasalahan ini. Dipilihnya pemikiran imam az-Zarnuji dalam penelitian ini paling tidak ada beberapa alasan; Pertama, karena dalam paradigma etika pendidikan Islam pemikiran tokoh tersebut mempunyai pengaruh yang sangat signifikan. Imam az-Zarnuji dengan karyanya Ta`li@mul Muta'allim menjadi kitab rujukan di pondok pesantren al-Ishlahuddiny Kediri Lombok Barat terutama dalam bidang akhlak. Kedua, metode dan petuah-petuah yang diungkapkan tokoh ini sangat cocok dikembangkan dalam proses belajar mengajar terutama dalam pendidikan Islam untuk saat ini.

Dari beberapa uraian di atas tentang peserta didik, untuk itu peneliti tertarik mengkaji tentang "Strategi Penerapan Konsep Peserta Didik Yang Ideal Menurut Imam az-Zarnuji Dalam Kitab Ta'limul Muta'allim Di Mahad Aly al-Ishlahuddiny Kediri Lombok Barat”.

\footnotetext{
1 Depertemen Agama, Peraturan Pemerintah Republik Indonesia Nomor 55 Tahun 2007 Tentang Pendidikan Agama Dan Pendidikan Keagamaan, (Jakarta: Departemen Agama, 2007), hal 2.

2 Observasi kegiatan santri di pondok pesantren al-Ishlahuddiny Kediri Lobar, tanggal 21 Februari 2019.

3 TGH. Nizom (pengampu kitab Ta'limul Muta'allim di Mahad Aly pondok pesantren al-Ishlahuddiny Kediri Lobar, Kediri, pada tanggal 22 Februari 2019.
}

\section{Copyright (C) 2019 Schemata Journal}

Available online at http://journal.uinmataram.ac.id/index.php/schemata 
Hamdani, A. Fattah, dan S. Jihad, Strategi Penerapan Konsep Peserta Didik yang Ideal...

\section{LANDASAN TEORI}

Penelitian yang peneliti lakukan akan mencoba meneliti tentang strategi penerapan konsep peserta didik yang ideal menurut Imam Az-Zarnuji dalam kitab Ta'limul Muta'allim di Mahad Aly pondok pesantren al-Ishlahuddiny Kediri Lombok Barat dan hasil strategi penerapannya. Untuk mempermudah peneliti dalam penelitian selanjutnya, maka perlu bagi peneliti untuk mengemukakan kerangka teori dalam melakukan penelitian ini, yaitu:

\section{Konsep Peserta Didik Menurut Landasan Normatif dan Yuridis Kenegaraan.}

Peserta didik adalah subjek yang terlibat dalam kegiatan belajar-mengajar di sekolah. ${ }^{4}$ Peserta didik merupakan sekelompok manusia yang dikatakan belum dewasa dalam artian jasmani maupun rohani memerlukan pendidikan, pembinaan, dan bimbingan dari orang lain yang dianggap dewasa agar peserta didik bisa mendapatkan tingkat kedewasaanya. Hal ini dimaksudkan agar peserta didik ketika dewasanya dapat mengerjakan tugasnya sebagai makhluk ciptaan Allah SWT, dan sebagai warga negara, warga masyarakat dan pribadi yang bertanggung jawab, serta manusia yang beretika.

Sebagaimana dijelaskan dalam UU RI tentang fungsi dan tujuan pendidikan nasional yang termaktub dalam pasal 3 UU RI tahun 2003, "Pendidikan nasional berfungsi mengembangkan kemampuan dan membentuk watak serta peradaban bangsa yang bermartabat dalam rangka mencerdaskan kehidupan bangsa. Adapun tujuan pendidikan nasional adalah "Berkembangnya potensi peserta didik agar menjadi manusia yang beriman dan bertakwa kepada Tuhan Yang Maha Esa, berakhlak mulia, sehat, berilmu, cakap, kreatif, mandiri, dan menjadi warga negara yang demokratis serta bertanggung jawab" (pasal 3 dan penjelasannya atas UU RI No. 20 tahun 2003). ${ }^{5}$

Oleh karena itu, belajar mempunyai peranan yang penting dalam kehidupan. Dengan belajar akan mengetahui segala peraturan dan larangan dalam kehidupannya sehingga akan melahirkan manusia yang beriman dan bertakwa kepada Allah SWT. Sebagaimana Allah SW'T berfirman dalam al-qur'an surah at-taubah ayat 122 yang berbunyi;

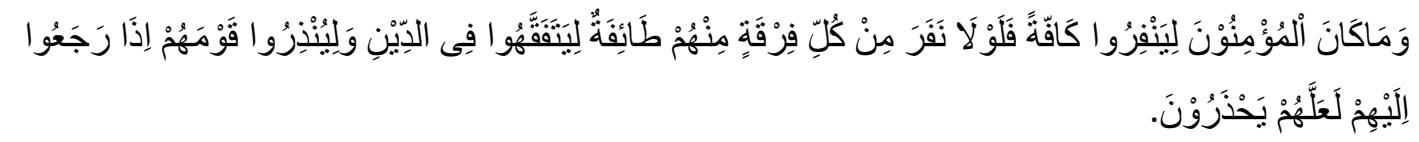

"Dan tidak sepatutnya orang-orang mukmin itu semuanya pergi (ke medan perang), mengapa sebagian dari setiap golongan di antara mereka tidak pergi untuk memperdalam pengetahuan

4Dimyati \& Mudjiono, Belajar Dan Pembelajaran, (Jakarta: Rineka Cipta, 2015), hal 22.

${ }^{5}$ Tim Redaksi Wirakrama, Seri Peraturan Perundang-Undang Republik Indonesia Tahun 2003, Jakarta: PT. Wirakrama Waskitha, 2003), hal 148.

\section{Copyright () 2019 Schemata Journal}

Available online at http://journal.uinmataram.ac.id/index.php/schemata 
Hamdani, A. Fattah, dan S. Jihad, Strategi Penerapan Konsep Peserta Didik yang Ideal...

agama mereka dan untuk memberi peringatan kepada kaumnya apabila mereka telah kembali agar mereka dapat menjaga dirinya". ${ }^{6}$

Dikatakan di dalam perspektif filsafat pendidikan Islam, dinamakan dengan peserta didik itu terdiri dari beberapa macam: (1) peserta didik merupakan darah daging pendidik itu sendiri, karena orang tua merupakan pendidik bagi semua anak-anaknya maka dari itu seluruh keturunannya menjadi anak didiknya didalam keluarganya; (2) peserta didik merupakansemua anak yang berada di bimbingan pendidik di suatu lembaga pendidikan formal maupun nonformal; (3) peserta didik secara khusus merupakan semua orang yang belajar di suatu lembaga pendidikan tertentu yang dalam keadaan menerima bimbingan, pengarahan, nasehat, pembelajaran, dan semua hal yang berhubungan dengan proses kependidikan. $^{7}$

Undang-undang pendidikan No. 20 tahun 2003 tentang Sistem Pendidikan Nasional (Sisdiknas), memakai istilah peserta didik bukan siswa, murid, pelajar atau mahasiswa sebab istilah peserta didik sudah mencakup segala unsur yang terdapat didalam diri peserta didik baik dari segi kebutuhan jasmani dan rohani, jalur pendidikan formal dan nonformal, anak-anak, remaja, dewasa, dan lanjut usia yang terus mengembangkan potensi kognitif, afektif dan psikomotoriknya. ${ }^{8}$

Untuk menunjang keberhasilan belajar peserta didik, maka peserta didik perlu memperhatikan prinsip-prinsip belajar yang berkaitan dengan; 1) perhatian dan motivasi,2) keaktifan, 3) keterlibatan langsung/berpengalaman, 4) pengulangan, 5) tantangan, dan 6) balikan dan penguatan. ${ }^{9}$

Sementara syarat-syarat yang harus ada dalam diri seorang peserta didik itu menururut Prof. Dr. Muhammad Athiyah al-Abrasyi antara lain: (1) Sebelum belajar, hendaknya peserta didik memulai dengan membersihkan hatinya dari sifat-sifat yang tidak baik seperti: dengki, hasud, penipu dan sombong, (2) Harus mempunyai akhlak yang mulia, (3) Hendaknya mengorientasikan belajarnya dalam rangka memperbaiki dan menghias jiwanya dengan sifat-sifat yang mulia. ${ }^{10}$

Idealnya menurut Berkson dan Wettersten, hal yang harus terjadi di dalam sebuah proses belajar yaitu bukan hanya sekedar pemindahan (transfer) tetapi juga

${ }^{6}$ Q.S at-Taubah [11]: 122.

${ }^{7}$ Hasan Basri, Filsafat Pendidikan Islam, (Bandung: Pustaka Setia, 2009), hal 88.

${ }^{8}$ Latifa Nur Batubara, Etika Peserta Didik Menurut Ilmu Dalam Kitab AL-Gunyah Li Talibi Tariq alHaqqi 'Azza Wa Jalla Karya Syekh Abdul Qadir al-Jailani, (Skripsi, UIN Sumatra Utara Medan, 2018), hal 17.

${ }^{9}$ Dimyati \& Mudjiono, Belajar \& Pembelajaran, (Jakarta: Renika Cipta, 2015), hal 42.

${ }^{10}$ Muhammad Athiyah al-Abrasyi, Beberapa Pemikiran Pendidikan Islam, alih bahasa: Syamsudin Asyrofi, A. Warid Khan, Nizar Ali, (Yogyakarta: Titian Ilahi Press, 1996), hal 73. 
Hamdani, A. Fattah, dan S. Jihad, Strategi Penerapan Konsep Peserta Didik yang Ideal...

transformasi/pengubahan dari segi kognitif, psikomotorik, maupun afektifnya. Sehingga demikian, belajar harus mencakup tiga aspek, yaitu kognitif, afektif dan psikomotorik. Ketiga aspek tersebut, harapannya dalam belajar bukan hanya sebagai pemenuhan intelektualnya saja melainkan juga dapat berfungsi sebagai transformasi atau mengubah tingkah laku individu itu sendiri. ${ }^{11}$

Dalam teori belajar akhlak menjelaskan bahwa pembentukan tingkah laku seorang muslim yang harapannya setelah mengalami proses belajar, seorang muslim sudah memiliki tingkah laku yang sesuai dengan ketentuan yang ada di dalam ajaran Islam. ${ }^{12}$

Di dalam teori belajar akhlak ini, memiliki tiga model pembelajaran yaitu taqlid (peniruan), tajribah wal khatta' (coba dan salah) dan ta'wid adapun penjelasannya sebagai berikut:

1) Taqlid (imitasi/peniruan)

Pada kebanyakan tingkah laku sekelompok manusia dan kebiasaannya merupakan hasil tiruan dari tingkah laku orang yang ada di sekitarnya. Suatu proses belajar akan bisa berjalan dengan maksimal apabila ada yang ditiru dari orang lain. Sehingga teori ini akan terwujud apabilaada orang lain ditiru dalam mengerjakan sesuatu maupun melafalkan suatu kata. Sebagaimana diungkapkan oleh Ibnu Sina tentang pengaruh tabiizyah terhadap anak yang cendrung mengikuti segala apa yang dilihat, dirasakan dan didengarnya. ${ }^{13}$

\section{2) Tajribiyyah wal khata'}

Seseorang juga bisa belajar melalui eksperimen pribadi dilakukan. Ada sebagian orang berusaha secara mandiri untuk memecahkan problem atau masalah yang dialaminya. Kebiasaannya seseorang didalam melakukan eksperimennya pasti akan mengalami beberapa kali ia melakukan kesalahan dalam memecahkan masalahnya, akan tetapi setiap kali kesalahan yang dialaminya oleh sebagian orang namun dia juga beberapa kali untuk mencoba melakukannya kembali sampai akhirnya dia mampu menyelesaikan permaslahannya dengan benar. Model semacam ini disebut sebagai teori trial and error (coba dan salah). ${ }^{14}$

\footnotetext{
${ }^{11}$ Izzatur Rusuli, "Refleksi Teori Belajar Behavioristik Dalam Perspektif Islam", Jurnal Pencerahan, Volume 8, No. 1, Juli-Desember 2014, hal 39.

12 Ibid, 47.

${ }^{13} \mathrm{Ibid}$

${ }^{14}$ Ibid, 48.
} 
Hamdani, A. Fattah, dan S. Jihad, Strategi Penerapan Konsep Peserta Didik yang Ideal...

3) Ta'wid

Baru dikatakan orang itu belajar dengan ta'wid/pembiasaan apabila terdapat stimulus yang merangsangnya. Pada waktu itulah seorang pelajar menggapai stimulus indrawi yang dinamakan dengan respon, kemudian respon tersebut diiringi dengan stimulus netral. Dalam hal tersebut telah diungkapkan oleh Hasan Langgulung yang menjelaskan tentang beberapa ketentuan yang harus dilakukansupaya proses belajar itu bisa berjalan dengan maksimal yaitu: ${ }^{15}$

a) Adanya perangsang/stimulus yang dikasih kepada peserta didik. Sementara perangsang tersebut harus mudah dapat dipahami oleh seorang yang belajar.

b) Peserta didik hendaknya melakukan pembalasan/respon kepada yang pemberi perngsang tersebut, apabila belajar tidak melakukan apa-apa ketika dikasih soal sehingga si peserta didik tadi tidak dinamakan belajar.

c) Respon hendaknya dikasih penguat supaya respon tersebut bersifat tetap.

Dari kedua teori yang telah disebut di atas yaitu teori belajar behavioristik dan teori belajar akhlak dapat disimpulkan bahwa teori belajar behavioristik adalah bersifat rasional, empiris, dan kuantitatif. Karena dibentuk berdasarkan menurut dunia sekuler, positifistik, dan materialistik. Sedangkan teori belajar akhlak merupakan kumpulan penjelasan dan penemuan akan prinsip-prinsip yang berhubungan terhadap peristiwa belajar yang dibangun berdasarkan pandangan dunia Islam yang bersumber dari al-qur'an dan as-sunnah yang dikembangkan oleh cendikiawan muslim.

\section{Konsep Peserta Didik Yang Ideal Menurut Imam Az-Zarnuji di Dalam Kitab}

Hamdani, A. Fattah, dan S. Jihad, Strategi Penerapan Konsep Peserta Didikyang Ideal...

Belajar sebagai sarana untuk memperoleh ilmu, haruslah melalui jalan dan persyaratan yang benar. Karena jalan yang benar dan persyaratan yang terpenuhi dalam belajar adalah kunci untuk mencapai keberhasilan belajar. Maka dari itu dalam kitab Ta'limul Muta'allim Imam Az-Zarnuji lebih memfokuskan pembahasannya pada jalan atau persyaratan (metode) yang harus ditempuh guna memperoleh keberhasilan belajar. Oleh karena itu sudah sepantasnya bagi para pencari ilmu harus mengetahui dan memahami syarat- syarat yang harus dipenuhi dalam mencari ilmu agar apa yang mereka

${ }^{15}$ Ibid, 49

\section{Copyright $\odot 2019$ Schemata Journal}

Available online at http://journal.uinmataram.ac.id/index.php/schemata 
Hamdani, A. Fattah, dan S. Jihad, Strategi Penerapan Konsep Peserta Didik yang Ideal...

harapkan bisa tercapai, yaitu mendapatkan ilmu yang bermanfaat dan bisa mengamalkannya. ${ }^{16}$

Melihat kenyataan tersebut, Imam Az-Zarnuji menyusun sebuah kitab yang diberi nama Ta'limul Muta'allim untuk membantu para pencari ilmu agar mereka mengetahui syarat-syarat yang harus mereka penuhi sebagai penuntut ilmu. Harapan dari penulis, kitab tersebut dapat membantu mengarahkan para penuntut ilmu melalui petunjukpetunjuk praktis, seperti bagaimana memilih ilmu, guru dan teman, waktu-waktu yang ideal untuk belajar, bagaimana metode belajar yang baik dan sebaginya.

Maka idealnya peserta didik menurut Imam Az-Zarnuji peserta didik itu harus; 1) berniat yang baik ketika belajar, 2) memilih ilmu, guru, dan teman yang baik, 3) menghormati ilmu dan guru/ahlinya, 4) bersungguh-sungguh, kuntinuitas dan bercitacita luhur, 5) mengetahui permulaan belajar, ukuran belajar dan tata tertibnya, 6) bertawakkal, 7) mengetahui waktu belajar ilmu/keberhasilan, mencari tambahan ilmu, 8) memiliki sifat waro', 9) mengetahui hal-hal yang dapat menguatkan hafalan dan yang melemahkannya. ${ }^{17}$

\section{METODE PENELITIAN}

Jenis penelitian yang digunakan untuk mengkaji mengenai Strategi Penerapan Konsep Peserta Didik Yang Ideal Menurut imam az-Zarnuji Dalam Kitab Ta'limul Mutáallim di Mahad Aly al-Ishlahuddiny Kediri dan hasil strategi penerapannya adalah penelitian kualitatif dengan pendekatan menggunakan pendekatan fenomenologi. Adapun teknik pengumpulan data yang digunakan dalam penelitian ini adalah observasi, wawancara, dan dokumentasi. Sedangkan data yang terkumpul kemudian dianalisis dengan menggunakan metode yang dikemukakan oleh Miles dan Huberman mengatakan bahwa suatu aktivitas untuk menganalisis data kualitatif yaitu dilakukan secara interaktif dan tidak bersifat sementara sampai tuntas yaitu sampai datanya dikatakan sudah mengalami kejenuhan. Adapun aktivitas yang harus dilakukan ketika menganalisis data, yaitu si peneliti melakukan data reduction, data display, dan conclusion drawing/verification.

${ }^{16}$ Noer, Muhammad Ali, dan Azin Sarumpet, Jurnal AL-HIKMAH, Volume 14, No. 2. Oktober 2017, ISSN 1412-5382, hal 195.

${ }^{17}$ Az-Zarnuji, Ta'limul Muta'allim, cet. Haromaen, hal 4. 
Hamdani, A. Fattah, dan S. Jihad, Strategi Penerapan Konsep Peserta Didik yang Ideal...

\section{HASIL DAN PEMBAHASAN}

\section{Strategi Penerapan Konsep Peserta Didik Yang Ideal Menurut Imam Az-Zarnuji Di Dalam Kitab Ta'limul Muta'allim Di Mahad Aly Pondok Pesantren Al- Ishlahuddiny Kediri Lobar}

a. Sikap Keteladanan

Dikatakan oleh TGH. Nizom selaku pengampu mata pelajaran kitab Talimul Muta'allim bahwa memberi contoh yang baik oleh seorang guru kepada muridnya sangatlah berperan dalam proses belajar mengajar, karena kebiasaan anak melakukan suatu perbuatan itu apa yang dilihat dan didengarnya dari gurunya. Maka dari itu guru itu hendaknya kalau menyuruh muridnya dalam suatu hal yang baik terlebih dahulu dikerjakan oleh guru tersebut. Sebagaimana dicontohkan oleh Nabi SAW kepada para sahabat dulu bahwa sebelum Nabi menyuruh sahabat, terlebih dahulu dikerjakan oleh Nabi SAW.

Metode keteladanan dalam pendidikan merupakan metode yang berpengaruh dan terbukti paling berhasil dalam mempersiapkan dan membentuk aspek moral, spritual, dan etos sosial anak. Sebab pendidik merupakan contoh yang ideal dalam pandangan anak. Pendidik adalah seorang figur terbaik dalam pandangan anak, yang tindak tanduk dan sopan-santunnya, disadari atau tidak, akan ditiru oleh mereka. Bahkan bentuk perkataan, perbuatan dan tindak tanduknya akan senantiasa tertanam dalam kepribadian anak. ${ }^{18}$

Dalam konteks Islam telah dijelaskan bahwa manusia termulia dan sebagai teladan yaitu Nabi Muhammad SAW ketika mengajarkan para sahabat beliau selalu memberikan keteladanan terlebih dahulu sebagaimana dijelaskan oleh Prof. Dr. Fadhl Ilahi dalam bukunya bahwa Rasulullah SAW dalam mengajarkan para sahabatnya tentang masalah agama, beliau sering menjelaskan dengan keteladanan atau perbuatan. Diantara buktinya adalah beliau mengajarkan para sahabatnya tentang banyak berzikir kepada Allah, memperhatikan shalat lima waktu, sifat darmawan, mendahulukan kepentingan orang lain (itsar), zuhud terhadap dunia dan seterusnya yang berkaitan dengan ibadah kepada Allah. ${ }^{19}$

Begitu pula menurut Abdullah Nasih Ulwan dalam bukunya mengatakan bahwa pendidikan dengan keteladanan berarti pendidikan dengan memberi contoh, baik berupa

18 Samsul Nizar \& Zaenal Efendi Hasibuan, Hadis Tarbawi, (Jakarta: Kalam Mulia, 2011), hal 71.

${ }^{19}$ Nurul Mukblisin Asyraf, Terjemahan Sirah Nabi Sebagai Guru Berdasarkan Al-qur'an dan Hadis-hadis Shahih, (Surabaya: Pustaka eLBA, 2012), hal 143. 
Hamdani, A. Fattah, dan S. Jihad, Strategi Penerapan Konsep Peserta Didik yang Ideal...

tingkah laku, sifat, cara berfikir, dan sebagainya. Banyak para ahli yang berpendapat bahwa pendidikan keteladanan merupakan metode yang paling berhasil. Hal ini karena dalam belajar orang pada umumnya, lebih mudah menangkap yang konkrit ketimbang yang abstrak. ${ }^{20}$

b. Pembiasaan

TGH. Nizom selaku pengampu mata pelajaran kitab Talimul Muta'allim di Mahad Aly Ponpes Al-Ishlahuddiny Kediri Lobar mengatakan bahwa dengan adanya pembiasaan ini diharapkan seluruh peserta didik dalam melaksanakan kegiatan-kegiatan yang sudah ditetapkan oleh pihak guru/ustadz di Mahad Aly pondok pesantren alIshlahuddiny Kediri Lobar menjadikan semua kegiatan dilakukan dengan senang hati sehingga peserta didik yang merasa dipaksa lama kelamaan sudah tidak terasa lagi sebagai paksaan dan cara menerapkan isi kitab Ta'limul Muta'allim dengan harapan mewujudkan peserta didik yang ideal.

Menurut Arief, ada beberapa syarat yang perlu diperhatikan dalam melakukan metode pembiasaan kepada anak-anak yaitu; (1) mulailah pembiasaan itu sebelum terlambat, sebelum anak itu mempunyai kebiasaan lain yang berlawanan dengan hal-hal yang akan dibiasakan; (2) pembiasaan itu hendaklah terus menerus atau berulang-ulang dijalankan secara teratur sehingga akhirnya menjadi suatu kebiasaan yang otomatis; (3) pendidikan hendaklah konsekuen, bersikap tegas dan tetap teguh terhadap pendiriannya yang telah diambilnya. Jangan memberikan kesempatan kepada anak untuk melanggar pembiasaan yang telah ditetapkan; (4) pembiasaan mula-mulanya mekanistis itu harus makin menjadi pembiasaan yang disertai kata hati anak sendiri. ${ }^{21}$

c. Berkhidmat

Mudabbir/pengurus Pondok yaitu Susanto merupakan salah satu cara menghormati ilmu dan ustaz supaya mendapat ilmu barokah yang diajarkan oleh para ustaz dan tuan guru adalah dengan cara berkhidmat kepada guru sebagaimana para tuan guru yang pernah belajar di ponpes al-Ishlahuddiny mereka kebanyakan berkhidmat dari pada pergi Mahad. Karena dengan berkhidmat kedekatan murid dengan guru semakin dekat sehingga murid tidak merasa kesulitan memahami suatu pelajaran karena ketika tidak paham langsung ditanyakan. Dan dengan berkhidmat murid itu akan mendapatkan ilmu

\footnotetext{
${ }^{20}$ Abdullab Nashib Ulwan, Pedoman Pendidikan Anak dalam Islam, (Semarang: CV Asy-Syifa, 1981), bal 163.

21 Arief, Pengantar Ilmu dan Metodologi Pendidikan Islam, (Jakarta: Ciputat Press, 2002), hal 114-115.
} 
Hamdani, A. Fattah, dan S. Jihad, Strategi Penerapan Konsep Peserta Didik yang Ideal...

barokah dan ilmu yang belum diajarkan oleh gurunya di Mahad, karena dengan berkhidmat peserta didik apabila mengalami kebingungan maka bisa ditanyakan langsung tanpa mengaji dengan membuka kitab seperti biasanya.

Disebutkan di dalam kitab Ta'limul Muta'allim, imam az-Zarnuji Menjelaskan bahwa dianjurkan kepada para penuntut ilmu agar memperhatikan seluruh ilmu dan hikmah dengan penuh ta'zim serta hormat, meskipun telah seribu kali ia mendengar keterangan dan hikmah yang itu-itu saja. Sehingga dalam kitab Ta'limul Muta'allim menjelaskan barang siapa ta'zimnya setelah seribu kali berulang tidak seperti ta'zimnya yang pertama kali, maka dia bukan ahli ilmu. ${ }^{22}$

Berkhidmat merupakan salah satu cara menarik perhatian dan kasih sayang guru kepada peserta didik. Karena proses belajar mengajar pada hakikatnya adalah proses transformasi rohani dari guru kepada murid. Karena itu kelancaran dan efektifitasnya sanagat ditentukan oleh kualitas hubungan rohaniah antara keduanya. Semakin akrab hubungan ruhani antara keduanya, maka semakin efektif transformasi ruhani yang terjadi, berarti semakin maksimal penularan ilmu keduanya. ${ }^{23}$

Karena berkhidmat juga merupakan salah satu yang terpenting yang harus dilakukan sebagai peserta didik yaitu berkhidmat kepada gurunya. Karena berkhidmat merupakan salah satu cara menghormati guru dan ilmu sehingga mendapatkan keberkahan ilmunya. Berdasarkan penngamatan penulis Sikap khidmat ini sebagian besar santri ponpes alIshlahuddiny Kediri Lobar menerapkannya ketika lulus Tsanawiah dan Aliah. Cara berkhidmat para santri yaitu ada dengan cara tinggal langsung di rumah gurunya dan ada yang melewati pondok. Sekalipun para santri telah lulus atau tamat sekolah ada juga yang berkhidmat sampai beberapa puluhan tahun.

d. Pemberian Nasihat

TGH. Nizom selaku pengampu mata pelajaran kitab Ta'limul Muta'allim mengatakan bahwa salah satu cara menyampaikan pelajaran yang cepat sampai dan berhasil kepada murid itu adalah dengan cara selalu diberikan nasihat. Menasihati bagaimana cara menuntut ilmu yang benar supaya mendapat ilmu yang berkah dan bermanfaat. Dan dengan nasihat itu dapat membantu memudahkan murid memahami suatu pelajaran. Nasihat dilakukan tidak hanya di dalam kelas akan tetapi dilakukan juga di luar kelas untuk sebagai pengingatan.

\footnotetext{
${ }^{22}$ Aliy As'ad, Terjemahan Ta'limul Muta'allim...,48

${ }^{23}$ Ibid 47.
} 
Hamdani, A. Fattah, dan S. Jihad, Strategi Penerapan Konsep Peserta Didik yang Ideal...

Disebutkan oleh Prof. Dr. Samsul Nizar di dalam bukunya bahwa pemberian nasihat ini merupakan metode yang penting digunakan untuk menggugah perasaan peserta didik. Karena pemberian nasihat ini mempunyai beberapa faedah yaitu; (1) tergugahnya perasaan Rabbaniyat pada diri peserta didik; (2) berfikir Rabbani yang sehat; (3) terbinanya jama'ah yang mukmin; (4) penyucian dan pembersihan jiwa yang merupakan tujuan dari pendidikan Islam. ${ }^{24}$

2. Hasil Strategi Penerapan Konsep Peserta Didik Yang Ideal Menurut Imam AzZarnuji Dalam Kitab Ta'limul Muta'allim Di Mahad Aly Pondok Pesantren AlIshlahuddiny Kediri Lobar.

a. Peserta Didik Mahad Aly Pondok Pesantren Al-Ishlabuddiny Kediri Lobar Terbiasa Menghormati Guru dan Ilmu.

TGH. Nizom selaku pengampu mata pelajaran kitab Ta'limul Muta'allim di Mahad Aly Ponpes Al-Ishlahuddiny Kedri Lobar menjelaskan bahwa dengan sikap pembiasaan menghormati dan memuliakan guru yang diajarkan dan diterapkan pendidik kepada peserta didiknya, maka peserta didik itu dengan sendirinya akan menerapkan dalam kehidupan sehari-harinya. Sehingga peserta didik ketika belajar dan bertemu dengan gurunya mereka memuliakan dan menghormatinya dengan cara mengucapkan salam kepada gurunya dan bersalaman, melaksanakan perintah gurunya ketika diperintah, dan tidak menyakiti hati gurunya.

Di dalam kitab Ta'limul Muta'allim menjelaskan bahwa pelajar tidak bakal mendapat ilmu dan tidak juga memetik manfaat ilmu selain dengan menghargai ilmu dan menghormati ahli ilmu/orang alim. Sebagaimana dikatakan dalam kata mutiara yaitu tiada keberhasilan seseorang dalam mencapai sesuatu kecuali dengan menghormatinya, dan tiada kegagalannya selain karena tidak mau menghormatinya. ${ }^{25}$

b. Peserta Didik Mahad Aly Pondok Pesantren Al-Ishlahuddiny Kediri Lobar Menjadi Memiliki Sifat Waro' Ketika Belajar.

Sebagaimana telah dijelaskan oleh mudabbir/pengurus Asrama Ponpes mengatakan bahwa dengan sebab pembiasaan-pembiasaan yang diajarkan dan diterapkan selama berada di pondok seperti teraturnya ketika makan dan tidur yaitu mereka dibiasakan tidak terlalu kenyang ketika makan, dan tidak terlalu banyak tidur, sehingga

\footnotetext{
${ }^{24}$ Samsul Nizar, Hadis Tarbawi...,78.

25 Aly As'ad, Terjemah Ta'limul Muta'allim...,33.
} 
Hamdani, A. Fattah, dan S. Jihad, Strategi Penerapan Konsep Peserta Didik yang Ideal...

mereka selalu menggunakan waktu-waktunya untuk belajar ilmu. karena dengan tidak terlalu kenyang ketika makan dan tidak terlalu banyak tidur merupakan salah satu cara menerapkan sifat waro' kepada peserta didik sebagaimana dijelaskan oleh para ustaz dan tuan guru.

Dan Imam Az-Zarnuji telah menjelaskan dalam kitab Ta'limul Muta'allim bahwa termasuk berbuat waro' adalah memelihara dirinya jangan sampai perutnya kenyang amat, terlalu banyak tidur dan banyak membicarakan hal yang tak bermanfaat. ${ }^{26}$

Dalam masalah waro' ini, sebagian ulama meriwayatkan hadis Nabi sebagai berikut yang artinya;

Barang siapa yang tidak berlaku waro' ketika belajar ilmu, maka dia akan diuji oleh Allah

dengan salah satu dari tiga macam ujian mati muda, ditempatkan bersama orang-orang

bodoh, atau diuji menjadi pelayan pemerintah.

Dari hadis di atas menunjukkan bahwa bersifat waro' ketika belajar ilmu itu akan membuat ilmunya bermanfaat dan belajarnya lebih mudah. Di dalam kitab Talimul Muta'allim dijelaskan bahwa yang termasuk sifat waro' ialah menghindari rasa kenyang, banyak tidur, dan menghindari banyak berbicara yang tidak berguna. ${ }^{27}$

c. Peserta Didik Mahad Aly Pondok Pesantren Al-Ishlabuddiny Kediri Lobar Menjadi Sabar Dan Tawakkal Ketika menuntut Ilmu.

Sebagaimana dijelaskan oleh salah satu guru Mahad Aly Ponpes Al-Ishlahuddiny Kediri Lobar menjelaskan bahwa dengan strategi penerapan berkhidmatnya atau pengabdiannya para peserta didik kepada gurunya ketika belajar ilmu, membuat peserta didik menjadi sabar dan tawakkal ketika belajar. Karena waktu berkhidmat kepada gurunya sangat lama, bahkan sampai beberapa puluhan tahun mengabdi/berkhidmat kepada gurunya mereka tidak dikasih pulang sebelum ada izin dari gurunya.

Selama para peserta didik berkhidmat, mereka digembleng dengan berbagai cara seperti disuruh pergi ke ladang guna bercocok tanam yang tidak kenal lelah dan panas, sehingga mereka para santri mempersiapkan kesabarannya untuk mendapatkan kasih sayang gurunya. Salah satu cara memperoleh kesabaran ketika belajar adalah dengan mengabdi/ berkhidmat kepada gurunya. Meraka para peserta didik tidak diizinkan pulang ke kampung halaman mereka sebelum mereka menguasai suatu bidang ilmu.

\footnotetext{
${ }^{26}$ Az-Zarnuji, Ta'limul Muta'allim...,66.

${ }^{27}$ Aly As'ad, Terjemah Ta'limul Muta'allim...,123.
} 
Hamdani, A. Fattah, dan S. Jihad, Strategi Penerapan Konsep Peserta Didik yang Ideal...

Ketahuilah sabar dan tabah adalah pangkal yang besar untuk segala urusan. Maka sebaiknya pelajar berhati tabah dan sabar dalam berguru, dalam mempelajari suatu kitab jangan tinggalkan terbengkalai dalam suatu bidang studi jangan berpindah ke bidang lain sebelum yang pertama sempurna dipelajari, dan dalam hal daerah belajar jangan berpindah ke daerah lain kecuali karena terpaksa. ${ }^{28}$

Sebagaimana telah dijelaskan oleh Imam Az-Zarnuji di dalam kitabnya bahwa dianjurkan kepada penuntut ilmu agar memperhatikan seluruh ilmu dan hikmah dengan penuh ta'zim serta hormat, meskipun telah seribu kali ia mendengar keterangan dan hikmah yang itu-itu saja. Sehingga dalam kitab Tali@mul Muta'allim menjelaskan barang siapa ta'zimnya setelah seribu kali berulang tidak seperti ta'zimnya yang pertama kali, maka dia bukan ahli ilmu. ${ }^{29}$

Dan dari pengamatan penulis juga para penuntut ilmu di Pondok Pesantren AlIshlahuddiny Kediri Lobar lebih banyak mencari ilmu yang barokah melewati berkhidmat ke para ustaz dan tuan guru yang mengajari mereka, bahkan mereka berlomba-lombaan untuk mencari kebarokahan ilmunya melalui berkhidmat. Karena asomsi mereka dengan berkhidmat kedekatan mereka semakin dekat dengan kedekatan itu mereka berharap untuk segala sesuatu yang mereka belum pahami mereka bisa bertanya langsung dan diajarkan sesuatu yang tidak pernah diajarkan ketika di majlis ilmu bersama murid-murid yang lain.

a. Peserta Didik Mahad Aly Pondok Pesantren Al-Ishlabuddiny Kediri Lobar Menjadi Disiplin.

Dari penjelasan TGH. Nizom selaku pengampu mata pelajaran kitab Talimul Muta'allim di Mahad Aly Pondok Pesantren Al-Ishlahuddiny Kediri Lobar menjelaskan bahwa dengan beberapa penerapan pembiasaan-pembiasaan di Mahad Aly Ponpes AlIshlahuddiny Kediri Lobar mereka menjadi disiplin. Ketika mereka melakukan suatu tindakan yang menjadi aturan yang harus mereka lakukan seperti datang tepat pada waktunya, menghafal ketika guru mereka belum datang di kelas dan menyetor hafalanhafalan yang sudah mereka hafal dengan tepat waktu berdasarkan waktunya yang sudah ditetapkan. Mereka selalu tertib dan patuh terhadap berbagai ketentuan dan peraturan.

Pembiasaan merupakan salah satu metode pendidikan yang sangat penting, terutama bagi anak-anak. Mereka belum menginsafi apa yang disebut baik dan buruk dalam arti susila. Mereka juga belum mempunyai kewajiban-kewajiban yang harus

\footnotetext{
${ }^{28}$ Aly As'ad, Terjemah Ta'limul Muta'allim...,31

${ }^{29}$ Aly As'ad, Terjemahan Ta'limul Muta'allim...,20.
}

\section{Copyright $(92019$ Schemata Journal}

Available online at http://journal.uinmataram.ac.id/index.php/schemata 
Hamdani, A. Fattah, dan S. Jihad, Strategi Penerapan Konsep Peserta Didik yang Ideal...

dikerjakan seperti pada orang dewasa. Sehingga mereka perlu dibiasakan dengan tingkah laku, keterampilan, kecakapan, dan pola pikir tertentu. Anak perlu dibiasakan pada sesuatu yang baik. Lalu mereka akan mengubah seluruh sifat-sifat baik menjadi kebiasaan, sehingga jiwa dapat menunaikan kebiasaan itu tanpa terlalu payah, tanpa kehilangan banyak tenaga, dan tanpa menemukan banyak kesulitan. ${ }^{30}$

Menurut Syaepul Manan dalam Jurnalnya, perilaku disiplin siswa merupakan yang tidak muncul dengan sendirinya, tetapi perlu ditanamkan. Oleh karena itu penanaman disiplin dapat dilakukan melalui dua cara. pertama yaitu disiplin preventif yang merupakan tindakan untuk mendorong para siswa mengikuti atau mematuhi normanorma dan aturan sehingga pelangaranpelanggaran tidak terjadi. Kedua, disiplin korektif, yaitu suatu kegiatan yang diambil untuk menangani pelanggaran terhadap aturan-aturan dan mencoba untuk menghindari pelangaran-pelanggaran lebih lanjut. ${ }^{31}$

\section{KESIMPULAN}

Berdasarkan hasil penelitian yang diperoleh, peneliti dapat menyimpulkan sebagai berikut:

1. Strategi Penerapan Konsep Peserta Didik Yang Ideal Menurut Imam Az-Zarnuji Di Dalam Kitab Ta'limul Muta'allim Di Mahad Aly Pondok Pesantren Al-Ishlahuddiny Kediri Lombok Barat.

Berdasarkan hasil penelitian yang diperoleh tentang strategi penerapan konsep peserta didik yang ideal menurut imam az-Zarnuji di dalam kitab Ta'limul Muta'allim di Mahad Aly pondok pesantren al-Ishlahuddiny Kediri Lobar meliputi tiga strategi yaitu a) sikap keteladanan melalui cara berpakaian, berkata sopan, dan cara membawa kitab. b) pembiasaan melalui menghormati guru, menghormati ilmu, sifat waro', dan menghafal matan kitab. c) berkhidmat, dan d) pemberian nasihat.

2. Hasil Strategi Penerapan Konsep Peserta Didik Yang Ideal Menurut Imam Az-Zarnuji Dalam Kitab Ta'limul Muta'allim Di Mahad Aly Pondok Pesantren Al-Ishlahuddiny Kediri Lobar.

Sedangkan hasil dari beberapa strategi penerapan konsep peserta didik yang ideal menurut Imam Az-Zarnuji dalam kitab Ta'limul Muta'allim di Mahad Aly Pondok

${ }^{30}$ Nata, Filsafat Pendidikan Islam, (Jakarta: Logos Wacana Ilmu, 1997), hal 101.

${ }^{31}$ Syaepul Manan, "Pembinaan Akblak. Mulalui Keteladanan Dan Pembiasaan", Jurnal Pendidikan Agama IslamTa'lim Vol. 15 No. 1 2017, hal 59.

\section{Copyright () 2019 Schemata Journal}

Available online at http://journal.uinmataram.ac.id/index.php/schemata 
Hamdani, A. Fattah, dan S. Jihad, Strategi Penerapan Konsep Peserta Didik yang Ideal...

Pesantren Al-Ishlahuddiny Kediri Lobar adalah a) peserta didik Mahad Aly Pondok Pesantren Al-Ishlahuddiny Kediri Lobar menjadi terbiasa menghormati guru dan ilmu, b) peserta didik Mahad Aly Pondok Pesantren Al-Ishlahuddiny Kediri Lobar menjadi memiliki sifat waro' ketika belajar, c) peserta didik Mahad Aly Pondok Pesantren AlIshlahuddiny Kediri Lobar menjadi sabar dan tawakkal ketika menuntut ilmu, dan d) peserta didik Mahad Aly Pondok Pesantren Al-Ishlahuddiny Kediri Lobar menjadi disiplin.

\section{DAFTAR PUSTAKA}

Anggoro, T. (2007) Metode Penelitian, Jakarta: Universitas Terbuka

Arief. (2002). Pengantar Imu dan Metodologi Pendidikan Islam, Jakarta: Ciputat Press

Az-Zarnuji. (2007). Ta'limul Muta'allim, Jawa: Cetakan Haromaen.

Basri, H. (2009) Filsafat Pendidikan Islam. Bandung: Pustaka Setia

Depertemen Agama. (2007). Peraturan Pemerintah Republik Indonesia Nomor 55 Tahun 2007 Tentang Pendidikan Agama Dan Pendidikan Keagamaan, Jakarta: Departemen Agama.

Dimyati \& Mudjiono, (2015). Belajar Dan Pembelajaran, Jakarta: Rineka Cipta

Hadi, S. (1987) Metode Reseach, Yogyakarta: Yayasan Penerbit Fak. Psikologi UGM

Hamid, H. dan Saebani, B. A. (2013). Pendidikan Karakter Perspektif Islam, Bandung: CV. Pustaka Setia

Izzatur, R., (2014) Refleksi Teori Belajar Behavioristik Dalam Perspektif Islam, Jurnal Penceraban, 8(1)

Latifa, N. B., (2018). Etika Peserta Didik Menurut Ilmu Dalam Kitab AL-Gunyah Li Talibi Tariq al-Haqqi ‘Azza Wa Jalla Karya Syekh Abdul Qadir al-Jailani, Skripsi, UIN Sumatra Utara Medan

Manan, S. (2017) Pembinaan Akhlak Mulia Melalui Keteladanan dan Pembiasaan, Jurnal Pendidikan Agama Islam-Ta'lim, 15(1)

Mokhamad M. U., (2018). Penerapan Konsep Tulu Az-Zaman Menurut Az-Zarnuji Di Pondok Pesantren Asma' Chusna Kranji Kedungwuni Pekalongan, Jurnal Pendidikan Agama Islam Universitas W abid Hasyim, Progress, 6(2)

Munandar, U. (1992) Mengembangkan Bakat Dan Kreativitas Anak Sekolah, Jakarta: PT Gramedia Widiasarana Indonesia

Narbuko, C. \& Ahmad, A. (1997). Metodologi Penelitian, Jakarta: Bumi Aksara

Noer, M. A., \& Azin, S., Jurnal Al-Hikmah, 14(2)

Nurul, M. A., (2012). Terjemahan Sirab Nabi Sebagai Guru Berdasarkan Al-qur'an dan Hadis-hadis Shabih, Surabaya: Pustaka eLBA

Raco, J.R., (2010) Metode Penelitian Kualitatif. Jakarta: Grasindo.

Rahman, A., (2016). Pendidikan Akhlak Menurut az-Zarnuji Dalam Kitab Ta’limul Muta'allim", Jurnal At-Ta'dib, 11(1)

Ramli, M. (2015). Hakikat Pendidik Dan Peserta Didik, Tarbiya Islamiyah, 5(1)

Samsul, N. \& Zaenal, E. H., (2011) Hadis Tarbawi, Jakarta: Kalam Mulia

\section{Copyright $\odot 2019$ Schemata Journal}

Available online at $\mathrm{http}: / /$ journal.uinmataram.ac.id/index.php/schemata 
Hamdani, A. Fattah, dan S. Jihad, Strategi Penerapan Konsep Peserta Didik yang Ideal...

Shafique, (2005) Filsafat Pendidikan al-Ghazali, Bandung: CV Pustaka Setia

Sugiyono, (2012) Metode Penelitian Pendidikan Pendekatan Kualitatif, Kuantitatif, dan R \& D, Bandung: Alfabeta

Sugiyono, (2014) Metode Penelitian Kuantitatif, Kualitatif dan R \& D, Bandung: Alfabeta.

Suharsimi, A., (2006) Prosedur Penelitian, Jakarta: Rineka Cipta

Sya'roni, (2007) Model Relasi Ideal Guru dan Murid Telaah atas Pemikiran az-Zarnuji dan KH, Hasyim Asy'ari, Yogyakarta: Teras

Tim Redaksi Wirakrama, (2003) Seri Peraturan Perundang-Undang Republik Indonesia Tabun 2003, Jakarta: PT. Wirakrama Waskitha

Zuhairini, (1995) Filsafat Pendidikan Islam, Jakarta: Bumi Aksara 